\title{
PERLINDUNGAN HUKUM TERHADAP KONSUMEN DALAM PERJANJIAN PEMBIAYAAN BERSAMA PADA PT. ADIRA FINANCE, Tbk \\ Oleh \\ Ratna Indayatun*) \\ ratnaindayatun@unis.ac.id
}

\section{Abstrak}

Pesatnya pertumbuhan ekonomi berimbas pada kebutuhan konsumsi masyarakat yang meningkat, untuk memenuhi kebutuhan masyarakat terhadap barang konsumtif maupun barang modal untuk itu diperlukan tambahan dana. Dana tersebut dapat diperoleh dari Lembaga Pembiayaan yang merupakan lembaga keuangan non-Bank salah satunya adalah PT. Adira Finance Tbk. Pokok permasalahan yang dibahas adalah bagaimana tanggung jawab PT. Adira Finance Tbk terhadap objek perjanjian yang hilang atau musnah dalam perjanjian bersama terhadap konsumen, dengan PT. Adira Finance Tbk, dan bagaimanakah perlindungan hukum terhadap konsumen dalam perjanjian pembiayaan bersama antara konsumen dengan PT. Adira Finance Tbk. Metode penelitian yang digunakan adalah penelitian normatif yang bersifat deskriptif analisis, dengan bersumber pada data sekunder, yang dianalisis secara kualitatif dan penarikan kesimpulan secara deduktif. Hasil penelitian menggambarkan bahwa PT. Adira Financae Tbk dapat menghindarkan diri untuk tidak bertanggung jawab sebagai tertuang dalam angka 14 huruf e isi perjanjian bersama dan perjanjian yang dikeluarkan secara sepihak oleh PT. Adira Finance, Tbk. selaku pelaku usaha tidak memberikan perlindungan hukum bagi konsumen, dalam arti bahwa isi perjanjian tersebut menempatkan konsumen selalu di pihak yang lemah.

\section{Kata Kunci : Perlindungan Hukum dan Perjanjian Pembiayaan Bersama}

\section{A.PENDAHULUAN}

Pada umumnya lembaga pembiayaan menggunakan bentuk perjanjian baku yang mengikat para pihak. Klausulaklausula dalam perjanjian tersebut telah dibuat sebelumnya oleh salah satu pihak tanpa melibatkan pihak yang lain, dan pihak yang lain tersebut tinggal menandatangani saja perjanjian yang sudah disediakan. Konsumen menerima dan memenuhi klausula-klausula yang telah dipersiapkan dengan risiko tidak akan memperoleh barang yang menjadi objek perjanjian, apabila ia tidak menandatangani.

*) Penulis adalah Dosen Fakultas Hukum Universitas Islam Syekh-Yusuf
Saat ini banyak lembaga pembiayaan (finance) dan bank (bank umum maupun perkreditan) menyelenggarakan pembiayaan bagi konsumen (consumer finance), sewa guna usaha (leasing), anjak piutang (factoring), sewa beli, mereka umumnya menggunakan tata cara perjanjian yang mengikutkan adanya jaminan fidusia bagi objek perjanjian pembiayaan konsumen. Apabila konsumen memperhatikan perjanjian baku yang diberikan pihak pelaku usaha maka perlu dipersoalkan klausulaklausula dimana pihak konsumen harus menyetujui salah satu klausula yang terdapat pada perjanjian pembiayaan, yang memuat : 
"Seluruh kewajiban debitur kepada kreditur, dapat ditagih seketika dan sekaligus, tanpa pemberita-huan secara tertulis terlebih dahulu kepada debitur atau somasi lagi, sehingga suatu peringatan dengan surat juru sita atau surat lainnya tidak diperlukan lagi, apabila terjadi salah satu keadaan, maka jaminan dipindahtangankan atau dija-minkan kepada pihak ketiga tanpa ijin tertulis sebelumnya dari kreditur, atau disita oleh instansi yang berwenang, atau hilang, rusak, atau musnah karena sebab apapun juga".

Apabila terjadi persoalan dimana pihak konsumen tidak membayar angsuran yang telah ditentukan pihak pelaku usaha, maka pihak pelaku usaha akan melakukan penarikan barang atau obyek perjanjian secara langsung berdasarkan isi perjanjian yang telah ditetapkan sebelumnya.

Untuk menghindari risiko terlalu besar karena obyek perjanjian dihilangkan, maka pihak kreditur menempuh jalan pintas dengan penarikan barang objek perjanjian secara langsung berdasarkan salah satu isi perjanjian tersebut, terlihat bahwa dalam perjanjian baku yang dibuat oleh pelaku usaha ada ketidakseimbangan hak dan kewajiban antara pihak pelaku usaha dan konsumen sehingga perlindungan hak yang sepihak terhadap pelaku usaha menimbulkan banyak resiko atau kerugian yang harus dipikul oleh pihak konsumen.

Berdasarkan latar belakang di atas, maka Penulis akan membahas dengan pokok permasalahan sebagai berikut :

1. Bagaimanakah tanggung jawab PT. Adira Finance Tbk terhadap obyek perjanjian yang hilang atau musnah dalam perjanjian bersama terhadap konsumen dengan PT. Adira Finance Tbk?
2. Bagaimanakah perlindungan hukum terhadap konsumen dalam perjanjian pembiayaan bersama antara konsumen dengan PT. Adira Finance Tbk?

\section{B. PEMBAHASAN}

\section{Perjanjian Pada Umumnya}

Dalam kehidupan sehari-hari manusia selalu terlibat dalam pergaulan dengan sesamanya, sehingga terjadi hubungan antar manusia yang disebut juga dengan hubungan antar individu. Hubungan antar individu menimbulkan perhubungan yang dapat bersifat perhubungan biasa dan perhubungan hukum. Hubungan hukum antara dua orang atau dua pihak atau lebih didahului oleh perbincangan-perbincangan di antara para pihak dan adakalanya mewujudkan suatu perjanjian atau perikatan, tetapi adakalanya tidak mewujudkan perjanjian atau perikatan. Hubungan hukum yang timbul karena perjanjian itu mengikat kedua belah pihak yang membuat perjanjian, sebagaimana daya mengikat UndangUndang.

Untuk memahami istilah mengenai perjanjian dan perikatan menurut Subekti "Perjanjian adalah suatu peristiwa dimana seseorang berjanji kepada seorang lainnya atau dimana dua orang itu saling berjanji untuk melaksanakan suatu hal". Menurut Sudikno Mertokusumo mengemukakan bahwa : "Perjanjian adalah hubungan hukum antara dua pihak atau lebih berdasarkan kata sepakat untuk menimbulkan akibat hukum".

Selanjutnya Pitlo mengatakan bahwa : "Perikatan adalah hubungan hukum yang bersifat kekayaan antara dua orang atau lebih, atas dasar mana pihak yang satu berhak (kreditur) dan pihak yang lain berkewajiban (debitur).

Berdasarkan hal tersebut, maka dapat disimpulkan bahwa di dalam suatu perjanjian minimal harus terdapat dua 
pihak, dimana kedua belah pihak yang saling bersepakat untuk menimbulkan suatu akibat hukum tertentu. Perjanjian merupakan sesuatu yang konkrit yang dapat dilihat dengan panca indera. Dalam praktek, perjanjian disebut juga kontrak yang menentukan hubungan hukum antara para pihak. Sedangkan perikatan bersifat abstrak namun diberi akibat oleh hukum, karena para pihak harus mematuhi hubungan hukum yang terjadi di antara para pihak.

Menurut KUHPerdata Pasal 1313 bahwa : "Perjanjian adalah suatu perbuatan dengan mana satu orang atau lebih mengikatkan dirinya terhadap satu orang atau lebih". Sedangkan yang dimaksud dengan perikatan, dapat ditentukan oleh Pasal 1234 Buku III KUH Perdata yang menentukan perikatan dapat bersumber pada Perjanjian dan Undang-Undang adalah : "Tiap-tiap perikatan adalah untuk memberikan sesuatu, untuk berbuat sesuatu, atau untuk tidak berbuat sesuatu". Perikatan yang bersumber dari Undang-Undang pada umumnya perikatan yang dilahirkan dan ditentukan secara khusus oleh UndangUndang, seperti ganti rugi, kewajiban mendidik anak, pekarang yang berdampingan dan lain-lain.

\section{Azas-azas Perjanjian}

Asas hukum itu umumnya tidak berwujud peraturan hukum yang konkrit tetapi merupakan latar belakang dalam pembentukan hukum positif. Menurut Sudikno Mertokusumo : "asas hukum adalah dasar-dasar atau petunjuk arah dalam pembentukan hukum positif. Asasasas tersebut adalah :

a. Asas Konsensualisme.

Asas konsensualisme ini berkaitan dengan saat lahirnya suatu perjanjian. Menurut asas ini, suatu perjanjian lahir seketika saat telah tercapainya suatu kesepakatan antara para pihak yang mengadakan perjanjian menge- nai unsur-unsur pokoknya. Berkaitan dengan hal ini menurut Subekti : "Asas konsensualisme mempunyai arti yang terpenting, yaitu bahwa untuk melahirkan perjanjian adalah cukup dengan dicapainya kata sepakat mengenai hal-hal pokok dari perjanjian tersebut, dan bahwa perjanjian sudah lahir pada saat atau detik tercapainya consensus.

b. Asas Kepercayaan

Seseorang yang mengadakan perjanjian dengan pihak lain harus dapat menumbuhkan kepercayaan di antara kedua pihak bahwa satu sama lain akan memenuhi prestasinya di kemudian hari. Tanpa adanya kepercayaan, maka perjanjian itu tidak mungkin akan diadakan oleh para pihak, dengan kepercayaan ini, kedua pihak mengikatkan dirinya kepada perjanjian yang mempunyai kekuatan mengikat sebagai undang-undang.

c. Asas Kekuatan Mengikat

Demikian seterusnya dapat ditarik kesimpulan bahwa di dalam perjanjian terkandung suatu asas kekuatan mengikat. Terikatnya para pihak pada apa yang diperjanjikan dan juga terhadap beberapa unsur lain sepanjang dikehendaki oleh kebiasaan dan kepatuhan dan kebiasaan akan mengikat para pihak.

d. Asas Persamaan Hak

Asas ini menempatkan para pihak di dalam persamaan derajat, tidak ada perbedaan, walaupun ada perbedaan kulit bangsa, kepercayaan, kekuasaan, jabatan dan lain-lain, masingmasing pihak wajib melihat adanya persamaan ini dan mengharuskan kedua pihak untuk menghormati satu sama lain sebagai manusia ciptaan Tuhan.

e. Asas Keseimbangan

Asas ini menghendaki kedua belah pihak untuk memenuhi dan melaksanakan perjanjian itu, asas keseim- 
bangan ini merupakan kelanjutan dari asas persamaan, kreditur mempunyai kekuatan untuk menuntut pelunasan prestasi melalui kekayaan debitur, namun kreditur memikul beban untuk melaksanakan perjanjian itu dengan baik.

f. Asas Moral

Asas ini terlihat dalam perikatan wajar, di mana suatu perbuatan sukarela dari seseorang tidak menimbulkan hak baginya untuk menggugat kontraprestasi dari debitur. Juga hal ini terlihat dalam zaakwaarneming dimana seseorang yang melakukan perbuatan dengan sukarela (moral) yang bersangkutan mempunyai kewajiban (hukum) untuk meneruskan dan menyelesaikan perbuatannya, asas ini terdapat dalam Pasal 1339 KUH Perdata. Faktor yang memberikan motivasi pada yang bersangkutan untuk melakukan perbuatan hukum adalah berdasarkan pada kesusilaan (moral), sebagai panggilan dari hati nuraninya.

g. Asas Kepatuhan

Asas ini dituangkan dalam Pasal 1339 KUH Perdata, asas kepatuhan disini berkaitan dengan ketentuan mengenai isi perjanjian.

h. Asas Kebiasaan

Asas ini diatur dalam Pasal 1339 jo Pasal 1347 KUH Perdata, yang dipandang sebagai bagian dari perjanjian. Suatu perjanjian tidak hanya mengikat untuk hal-hal yang diatur secara tegas, tetapi juga hal-hal yang dalam keadaan dan kebiasaan yang diikuti.

i. Azas Kepatian Hukum

Perjanjian sebagai suatu figure hukum harus mengandung kepastian hukum. Kepastian ini terungkap dari kekuatan mengikat perjanjian itu, yaitu sebagai undang-undang bagi para pihak.

\section{Syarat Sah Perjanjian}

Ketentuan syarat sah perjanjian ditentukan dalam Pasal 1320 KUH Perdata yang harus memenuhi empat syarat sebagai berikut :

a. Sepakat mereka yang mengikatkan diri.

b. Cakap untuk melakukan perbuatan hukum atau membuat suatu perjanjian.

c. Mengenai suatu hal tertentu.

d. Suatu sebab yang halal.

Apabila unsur obyektif tidak terpenuhi maka perjanjian tersebut dapat "batal demi hukum", artinya bahwa perjanjian tersebut dianggap tidak ada, oleh karena itu para pihak yang merasa dirugikan tidak mempunyai dasar untuk melakukan gugatan.

1. Sepakat mereka yang mengikatkan diri

2. Cakap untuk melakukan perbuatan hukum atau membuat suatu perjanjian

3. Suatu hal tertentu

4. Suatu sebab yang halal.

\section{Prestasi, Wanprestasi dan Akibat- akibatnya}

Wujud prestasi adalah berbuat sesuatu dan tidak berbuat sesuatu. Berbuat sesuatu adalah melakukan sesuatu perbuatan yang telah ditetapkan dalam perjanjian. Sedangkan tidak berbuat sesuatu adalah tidak melakukan sesuatu perbuatan sebagaimana juga yang telah ditetapkan dalam perjanjian, manakala para pihak telah menunaikan prestasinya maka perjanjian tersebut akan berjalan sebagaimana mestinya tanpa menimbulkan persoalan. Namun, kadangkala ditemui bahwa debitur tidak bersedia melakukan atau menolak memenuhi prestasi sebagaimana yang telah ditentukan dalam perjanjian. Hal inilah yang disebut dengan wanprestasi.

Pada umumnya debitur dikatakan wanprestasi manakala ia karena 
kesalahannya sendiri tidak melaksanakan prestasi, atau melakukan sesuatu yang menurut perjanjian tidak diperbolehkan untuk dilakukan. Menurut Subekti melakukan prestasi tetapi tidak sebagaimana mestinya juga dinamakan wanprestasi. Yang menjadi persoalan adalah sejak kapan debitur dapat dikatakan wanprestasi. Mengenai hal tersebut perlu dibedakan wujud atau bentuk prestasinya. Sebab untuk prestasi ini sangat menentukan sejak kapan seorang debitur dapat dikatakan telah wanprestasi.

Akibat hukum dari debitur yang telah melakukan wanprestasi adalah hukuman atau sanksi sebagai berikut :

1. Debitur diharuskan membayar ganti kerugian yang telah diderita oleh kreditur (Pasal 1243 KUH Perdata).

2. Dalam perjanjian timbal balik (bilateral) wanprestasi dari suatu pihak memberikan hak kepada pihak lainnya untuk membatalkan atau memutuskan perjanjian lewat hakim (Pasal 1266 KUH Perdata).

3. Resiko beralih kepada debitur sejak saat terjadinya wanprestasi (Pasal 1237 (2) KUH Perdata). Ketentuan ini hanya berlaku bagi perikatan untuk memberikan sesuatu.

4. Membayar biaya perkara apabila perkara diperkirakan di muka hakim.

5. Debitur yang terbukti melakukan wanprestasi tentu dikalahkan dalam perkara. Ketentuan ini berlaku untuk semua perikatan.

6. Memenuhi perjanjian jika masih dapat dilakukan atau pembatalan perjanjian disertai dengan pembayaran ganti kerugian (Pasal 1267 KUH Perdata). Ini berlaku untuk semua perikatan.

\section{Overmacht dan Resikonya}

Tidak terpenuhinya prestasi itu kadangkala disebabkan karena adanya suatu peristiwa yang tidak dapat diduga sebelumnya oleh para pihak, sehingga hal tersebut mengakibatkan debitur tidak dapat memenuhi prestasinya. Dalam hal yang demikian, maka timbul persoalan yang dinamakan overmacht dan resiko.

Saherodji berpendapat bahwa overmacht merupakan suatu keadaan memaksa atau suatu keadaan/kejadian yang tidak dapat diduga-duga terjadinya, sehingga menghalangi seseorang debitur untuk melakukan prestasi sebelum ia lalai/alpa, dan keadaan mana tidak dapat dipersalahkan kepadanya.

Terjadinya overmacht mengakibatkan adanya resiko, yang dimaksud resiko, menurut Subekti adalah perkataan resiko berarti kewajiban untuk memikul kerugian yang disebabkan karena suatu kejadian di luar kesalahan salah satu pihak".

\section{Berakhirnya Perjanjian}

Suatu perjanjian akan berakhir bilamana tujuan perjanjian itu telah dicapai, dimana masing-masing pihak telah saling menunaikan prestasi yang diperlukan sebagaimana yang mereka kehendaki bersama-sama dalam perjanjian tersebut. Pasal 1381 KUH Perdata menyebutkan sepuluh cara hapusnya suatu perikatan, cara-cara tersebut adalah :

1. Penawaran

2. Penawaran pembayaran tunai diikuti dengan penyimpanan atau penitipan

3. Pembaharuan utang

4. Perjumpaan utang atau kompensasi

5. Pencampuran uang

6. Pembebasan utang

7. Musnahnya barang terutang

8. Batal/pembatalan

9. Berlakunya suatu syarat batal;

10. Lewatnya waktu

\section{Pembiayaan Konsumen}

Lahirnya sebuah perusahaan pembiayaan konsumen dalam sistem keuangan negara diatur oleh suatu lembaga, yaitu Lembaga Keuangan dan Lembaga Pembiayaan. Lembaga Keuangan adalah badan usaha yang mempunyai kekayaan 
dalam bentuk aset keuangan. Lembaga pembiayaan dalam kegiatan usahanya lebih menekankan pada fungsi pembiayaan.

Secara garis besar Lembaga Keuangan dapat diklasifikasikan menjadi 3 kelompok, yaitu :

1. Lembaga keuangan bank (LKB)

2. Lembaga keuangan bukan bank (LKBB)

3. Perusahaan pembiayaan

Pada perkembangannya untuk meningkatkan peranan Lembaga Keuangan Pemerintah menerbitkan Peraturan Presiden No. 9 Tahun 2009 yang ditetapkan pada tanggal 18 Maret 2009 tentang Lembaga Pembiayaan. Untuk peraturan pelaksanannya menggunakan peraturan Menteri Keuangan Republik Indonesia No. 84/PMK.012/2006 tentang Perusahaan Pembiayaan, Peraturan Menteri Keuangan No. 100/PMK.010/2009 tentang Perusahaan Pembiayaan Infrastruktur dan yang terakhir adalah Peraturan Menteri Keuangan No. 43/PMK.010/2012 tentang Uang Muka Pembiayaan Konsumen untuk Kendaraan Bermotor pada Perusahaan Pembiayaan.

\section{Perlindungan Hukum Terhadap Konsumen}

Peraturan Perundangan Konsumen yang dibuat dalam suatu Undang-Undang baru terealisasi tahun 1999 melalui UU Nomor 8 Tahun 1999 tentang Perlindungan Konsumen, yang diundangkan pada tanggal 20 April 1999 dalam Lembaran Negara tahun 1999 Nomor 42, dan berlaku efektif satu tahun setelah diundangkan yaitu sejak tanggal 20 April 2000. Hukum perlindungan konsumen sebagaimana dimaksud, yaitu :

1. Dilihat dari konteks hidup bernegara

2. Dilihat dari penegakan hukumnya

\section{Perlindungan Konsumen}

Perlindungan konsumen yang terdapat dalam Pasal 1 angka 1 UU Nomor 8
Tahun 1999 tentang Perlindungan Konsumen yaitu : "Perlindungan konsumen adalah segala upaya yang menjamin adanya kepastian hukum untuk memberikan perlindungan kepada konsumen".

Tujuan penyelenggaraan, pengembangan dan pengaturan perlindungan konsumen yang direncanakan adalah untuk meningkatkan martabat dan kesadaran konsumen, dan secara tidak langsung mendorong pelaku usaha dalam penyelenggaraan kegiatan usahanya dengan penuh rasa tanggung jawab.

\section{Tinjauan Umum PT. Adira Finance, Tbk}

PT. Adira Dinamika Multi Finance Tbk atau Adira Finance didirikan pada tahun 1990 dan mulai beroperasi pada tahun 1991. Sejak awal perusahaan telah berkomitmen untuk menjadikan perusahaan yang terbaik dan terkemuka untuk pembiayaan yang melayani pembiayaan beragam merek, baik untuk sepeda motor maupun mobil, baru maupun bekas. Melihat pada adanya potensi untuk mengembangkan usaha lebih lanjut PT. Adira Finance Tbk melakukan penawaran umum perdana atas sahamnya pada tahun 2003, yang mana Bank Danamon menjadi pemegang saham mayoritas dengan kepemilikan saham sebesar $75 \%$, dilanjutkan dengan melakukan akuisisi selanjutnya sebesar $20 \%$ saham, menjadi Bank Danamon memiliki kepemilikan saham sebesar 95\% pada tahun 2009. Dengan demikian, Adira Finance menjadi bagian dari termasuk Holdings, perusahaan investasi plat merah asal Singapura.

Tanggungjawab PT. Adira Finance, Tbk Jika Obyek Perjanjian Hilang Atau Musnah Dalam Perjanjian Pembiayaan Bersama Antara Konsumen Dengan PT. Adira Finance, Tbk.

Hubungan hukum antara dua orang atau dua pihak atau lebih adakalanya mewujudkan suatu perjanjian atau perikatan, tetapi adakalanya tidak mewujud- 
kan perjanjian atau perikatan. Hubungan hukum yang timbul karena perjanjian itu mengikat kedua belah pihak yang membuat perjanjian, sebagaimana daya mengikat Undang-Undang, sehingga Perjanjian yang dibuat mengikat kedua belah pihak, hal ini sesuai dengan Pasal 1338 ayat (1) KUH Perdata yang berbunyi: "Semua persetujuan yang dibuat secara sah berlaku sebagai Undang-Undang bagi mereka yang membuatnya".

Dalam suatu perjanjian minimal harus terdapat dua pihak, dimana kedua belah pihak sating bersepakat untuk menimbulkan suatu akibat hukum tertentu. Perjanjian merupakan sesuatu yang kongkrit yang dapat dilihat dengan panca indera. Dalam praktek, perjanjian disebut juga kontrak yang menentukan hubungan hukum antara para pihak. Sedangkan perikatan bersifat abstrak namun diberi akibat oteh hukum, karena para pihak harus mematuhi hubungan hukum yang terjadi di antara para pihak.

Ikatan yang lahir dari perjanjian yang demikian dinamakan perikatan. Jadi dapat dikatakan bahwa perjanjian menimbulkan suatu perikatan antara dua orang yang membuat, sehingga perikatan menunjukkan adanya suatu hubungan hukum antara para pihak yang berisi hak dan kewajiban masing-masing. Dan perjanjian menunjukkan suatu janji atau perbuatan hukum yang sating mengikat antara para pihak.

Dalam membuat suatu perjanjian ada ketentuan-ketentuan yang harus dipenuhi, yaitu ketentuan syarat sahnya perjanjian berdasarkan Pasal $1320 \mathrm{KUH}$ Perdata yang harus memenuhi empat syarat sebagai berikut:

1. Sepakat mereka yang mengikatkan diri

2. Cakap untuk melakukan perbuatan hukum atau membuat suatu perjanjian

3. Mengenai suatu hal tertentu

4. Suatu sebab yang halal

\section{Sepakat Mereka Yang Mengikatkan Diri}

Dalam suatu perjanjian, kata sepakat merupakan syarat yang utama karena kata sepakat merupakan pernyataan kehendak atau setuju dari para pihak untuk melakukan perjanjian atas isi akta perjanjian itu sendiri, artinya bahwa apa yang dikehendaki pihak yang satu dikehendaki pula oleh pihak yang lainnya. Dengan kesepakatan yang telah mereka nyatakan baik dengan lisan atau tulisan maka kesepakatan itu mengikat bagi para pihak, akan tetapi kesepakatan itu akan cacat dan batal atau dapat dibatalkan jika kesepakatan itu dibuat karena kehilafan/kesesatan, paksaan dan penipuan (Pasal 1321 KUH Perdata).

Perjanjian pembiayaan bersama yang penulis teliti, dimana PT. Adira Finance, Tbk setuju untuk memberikan fasilits pembiayaan bersama kepada konsumen yaitu dengan Bapak Ade Firman. Fasilitas Pembiayaan Bersama yang diberikan PT. Adira Finance kepada Bapak Ade Firman disebut "Fasilitas Pembiayaan Bersama dengan penyerahan Hak atas fidusia" yaitu:

PT. Adira sepakat untuk;

1) Memberikan Fasilitas Pembiayaan Bersama kepada konsumen sebesar Rp. 9.968.240,00 (Pasal 1 akta Perjanjian);

2) Menyimpan faktur cash dan Bukti Pemilikan Kendaraan Bermotor/BPKB Jaminan sampai seluruh kewajiban Konsumen kepada Pelaku Usaha dibayar lunas (syarat perjanjian angka 16 huruf a);

3) Berhak mendapat pembayaran bunga sebesar 26,96 \% dari Bapak Ade Firman (Pasal 1 akta perjanjian);

4) Meminta jaminan tambahan kepada Bapak Ade Firman, dengan tetap memperhatikan ketentuan peraturan perundang-undangan yang berlaku. (Pasal 2 akta Perjanjian);

5) Berhak atas seluruh kewajiban Kon- 
sumen untuk dapat ditagih seketika dan sekatigus tanpa pemberitahuan secara tertulis terlebih dahulu kepada debitur atau tanpa somasi lagi (angka 14 huruf d syarat perjanjian);

6) Menentukan seluruh jumlah kewajiban debitur, baik berupa pokok pinjaman, sisa pokok pinjaman, bunga, denda, biaya pelelangan/penjualan, honorarium pengacara/kuasa untuk menagih serta biaya-biaya lainnya yang timbut sehubungan dengan Perjanjian ini (termasuk penjuatan BJDA) (angka 14 huruf g syarat perjanjian);

7) Mengalihkan baik sebagian atau seluruhnya hak-hak dan kewajibankewajiban PT. Adira Finance, Tbk yang timbut dari Perjanjian ini kepada pihak ketiga lainnya (Angka 16 syarat perjanjian);

8) Seluruh kewajiban Bapak Ade Firman kepada PT. Adira Finance, Tbk, dapat ditagih seketika dan sekaligus tanpa pemberitahuan secara tertulis terlebih dahulu kepada Bapak Ade Firman atau tanpa somasi lagi, sehingga suatu peringatan dengan surat juru sita atau surat lainnya tidak diperlukan lagi. Apabila terjadi salah satu keadaan;

9) Apabila Bapak Ade Firman tidak melunasi seluruh atau sebagian kewajibannya kepada PT. Adira Finance, Tbk, maka Maka PT. Adira Finance, Tbk berhak dan dengan ini diberi kuasa dengan hak substitusi oleh Bapak Ade Firman;

10) Setelah jaminan ditarik atau diambil alih oleh PT. Adira Finance, Tbk ("BJDA'), PT. Adira Finance, Tbk berhak;

11) Uang hasil penjualan BJDA, akan diperuntukan untuk;
a) Ongkos dan pajak yang timbul sehubungan dengan penjualan BJDA;
b) Pokok pinjaman;

c) Kewajiban Iainnya termasuk bunga dan denda (jika ada). Apabila masih terdapat sisa uang, Kreditur akan menyerahkan sisa tersebut kepada Debitur dan/atau Penjamin, sebaliknya apabila uang hasil penjualan itu tidak cukup untuk melunasi seluruh kewajiban Bapak Ade Firman kepada PT. Adira Finance, Tbk, maka Bapak Ade Firman tetap berkewajiban membayar sisa kewajiban yang masih terhutang tersebut kepada kreditur selambat-lambatnya dalam waktu satuminggu setelah pemberitahuan PT. Adira Finance kepada Bapak Ade Firman." (Syarat perjanjian angka 14 huruf f).

Bapak Ade Firman sepakat untuk;

1) Membayar angsuran perbulan $\mathrm{Rp}$. 431.000, Jangka waktu angsuran 33 kali Angsuran, dimana angsuran pertama dimulai tanggal 14 Desember 2011 sedangkan angsuran selanjutnya dibayar pada tanggal yang sama tanggal angsuran pertama. (Pasal 1 Akta Perjanjian);

2) Membayar biaya administrasi Rp. 1.168.240,00, Uang Muka Jaminan 29.88\% Rp. 3.750.000,00. (Pasal 1 Akta Perjanjian);

3) Menjaminkan barang jaminan berupa kendaraan bermotor (Pasal 2 akta perjanjian);

4) Membayar biaya-biaya yang ditentukan Pelaku Usaha yaitu biaya administrasi dan uang muka jaminan (Pasal 2 akta Perjanjian);

5) Memberi kuasa kepada Pelaku Usaha untuk dan atas nama konsumen untuk membuat surat pesanan atas jaminan kepada penjual dan mempergunakan fasilitas pembiayaan bersama (syarat perjanjian angka 3);

6) Membayar angsuran, biaya-biaya ataupun denda yang wajib dibayar 
(jika ada) secara tepat waktu dan penuh sesuai dengan perjanjian ini (syarat perjanjian angka 4);

7) Memberitahukan secara tertulis kepada PT. Adira Finance, Tbk selambat-lambatnya 30 (tiga puluh) hari kalender sejak perubahan tersebut terjadi berkenaan dengan adanya perubahan data pokok dari Konsumen (syarat perjanjian angka 5);

8) Membayar denda untuk setiap hari keterlambatan pembayaran sebesar $0,5 \%$ fasilitas pembiayaan denda harus dibayar secara seketika dan sekaligus tanpa diperlukan teguran untuk itu pada saat ditagih (perjanjian angka 6);

9) Memelihara dan mengurus jaminan tersebut sebaikbaiknya dan melakukan pemeliharaan dan perbaikan atas biaya Konsumen bila ada bagian dari jaminan yang diganti atau ditambah, maka bagian tersebut termasuk dalam penyerahan secara fiducia kepada Pelaku Usaha (syarat perjanjian angka 14 huruf c);

10) Mendapatkan pencairan fasilitas pembiayaan bersama dilakukan oleh Pelaku Usaha setelah Konsumen memenuhi seluruh kewajiban yang ditentukan oleh Pelaku Usaha (syarat perjanjian angka 1 );

11)Bisa melakukan pembayaran dipercepat baik sebagian atau seluruhnya (syarat perjanjian angka 7);

12)Berkaitan dengan jaminan tetap dalam penguasaan oleh Konsumen tidak lagi sebagai pemilik melainkan sebagai peminjam atau pemakai jaminan (syarat perjanjian angka 14 huruf a);

\section{Cakap Untuk Melakukan Perbuatan Hukum Atau Membuat Suatu Perjanjian}

Menurut R. Subekti bahwa orang yang membuat suatu perjanjian harus cakap menurut hukum. Pada azasnya, setiap orang yang sudah dewasa atau akil-baliq dan sehat pikirannya, adalah cakap menurut hukum.

Dalam Pasal 1330 KUH Perdata disebutkan bahwa sebagai orang-orang yang tidak cakap untuk membuat suatu perjanjian:

a. Orang-orang yang belum dewasa,

b. Mereka yang ditaruh di bawah pengampuan,

c. Orang perempuan dalam hal-hal yang ditetapkan oleh undang-undang, dan pada umumnya semua orang kepada siapa Undang-undang telah melarang membuat membuat perjanjian-perjanjian tertentu.

Para Pihak Dalam Perjanjian bersama adalah :

a. PT. Adira Dinamika Multi Finance Tbk, diwakili oleh Lianah bertindak dalam kedudukannya selaku kuasa Perseroan;

b. Ade Firman beralamat di Villa Tomang Baru Blok J 2 no 11) 1/15 GelamJaya dalam hal ini bertindak untuk dirnya sendiri.

Ibu Lianah dan Bapak Ade Firman adalah orang dewasa yang menurut Pasal 330 KUHPerdata mereka sudah lebih dari 21 tahun dan telah menikah, mereka juga tidak ditaruh di bawah pengampuan serta tidak termasuk orang yang dilarang oleh Undang-undang untuk membuat perjanjian. Dengan kesadarannya mereka melakukan perbuatan hukum yaitu membuat perjanjian pembiayaan bersama. Atas perbuatannya mereka mengetahui hak dan kewajiban masing-masing sesuai dengan perjanjian yang mereka sepakati.

\section{Suatu Hal Tertentu}

Berdasarkan Pasal 1333 KUH Perdata;

a. Suatu persetujuan harus mempunyai sebagai pokok suatu barang yang paling sedikit ditentukan jenisnya.

b. Menerangkan bahwa tidaklah menjadi halangan bahwa jumlah barang tidak 
tentu, asal saja jumlah itu dikemudian hari dapat ditentuan atau dihitung.

Artinya bahwa suatu hal tertentu dalam perjanjian adalah barang yang menjadi obyek dalam suatu perjanjian, prestasi perjanjian harus tertentu atau dapat ditentukan.

Dalam perjanjian pembiayaan bersama antara PT. Adira Finance, Tbk dengan Bapak Ade Firman, yang menjadi objek pemberian pembiayaan bersama adalah sepeda motor merek Yamaha Mio CW dan Nomor mesin 2SD-3435531, yang kemudian dijaminkan dengan nilai jaminan sebesar Rp. 12.550.000,00, Nilai Penjaminan (Nilai AR) : Rp. 16.804.757,00

\section{Suatu Sebab Yang Halal}

Mengenai syarat ini, dalam Pasal 1335 KUH Perdata menyatakan bahwa "suatu perjanjian tanpa sebab, atau yang telah dibuat karena sesuatu sebab yang palsu atau terlarang, tidak mempunyai kekuatan". Hal ini dipertegas lagi dalam Pasal 1337 KUH Perdata yang menyatakan bahwa "suatu sebab adalah terlarang, apabila dilarang oleh UndangUndang, atau apabila berlawanan dengan kesusilaan baik atau ketertiban umum". Perjanjian Pembiayaan Bersama antara PT. Adira Finance, Tbk dengan Bapak Ade Firman bukan merupakan perjanjian yang palsu atau terlarang atau berlawanan dengan kesusiaan serta tidak melanggar ketertiban umum, sehingga mempunyai kekuatan hukum yang tetap dan mengikat kedua balah pihak.

Asas konsensualisme ini berkaitan erat dengan saat lahirnya suatu perjanjian. Menurut asas ini, suatu perjanjian lahir seketika saat telah tercapainya suatu kesepakatan antara para pihak yang mengadakan perjanjian mengenai unsur-unsur pokoknya. Asas konsensualisme mempunyai arti yang terpenting, yaitu bahwa untuk melahirkan perjanjian adalah cukup dengan dicapainya kata sepakat mengenai hal-hal pokok dari perjanjian tersebut, dan bahwa perjanjian sudah lahir pada saat atau detik tercapainya consensus, dalam perjanjian pembiayaan bersama antara PT. Adira Finance dengan Bapak Ade Firman sah menjadi perjanjian ketika Bapak Ade Firman menandatangani perjanjian yang diserahkan pihak Adira.

Seseorang yang mengadakan perjanjian dengan pihak lain harus dapat menumbuhkan kepercayaan di antara kedua pihak bahwa satu sama lain akan memenuhi prestasinya di kemudian hari. Tanpa adanya kepercayaan, maka perjanjian itu tidak mungkin akan diadakan oleh para pihak, dengan kepercayaan ini, kedua pihak mengikatkan dirinya kepada perjanjian yang mempunyai kekuatan mengikat sebagai undang-undang.

Dalam Asas Persamaan Hak dimana asas ini menempatkan para pihak di dalam persamaan derajat, tidak ada perbedaan, walaupun ada perbedaan kulit bangsa, kepercayaan, kekuasaan, jabatan, dan lain-lain, masingmasing pihak wajib melihat adanya persamaan ini dan mengharuskan kedua pihak untuk menghormati satu sama lain sebagai manusia ciptaan Tuhan, hal ini dilaksanakan sepenuhnya oleh PT. Adira Finance,Tbk dengan Bapak Ade Firman.

Berdasarkan Pasal 1 angka (7) Peraturan Presiden No 9 Tahun 2009 tentang Lembaga Pembiayaan bahwa Pembiayaan Konsumen (Consumer Finance) merupakan kegiatan pembiayaan untuk pengadaan barang berdasarkan kebutuhan konsumen dengan pembayaran secara angsuran. Pembiayaan Konsumen menurut Pasal 1 Angka (2) Perpres No 9 Tahun 2009 merupakan salah satu bentuk usaha dari Perusahaan Pembiayaan. Dan menurut Peraturan Menteri Keuangan No 84/PMK.012/2006 menjelaskan bahwa Perusahaan Pembiayaan adalah badan usaha di luar Bank dan Lembaga Keuangan Bukan Bank yang khusus didirikan untuk melakukan kegiatan yang terma- 
suk dalam bidang usaha Lembaga Pembiayaan. PT. Adira Finance, Tbk merupakan Perusahaan Pembiayaan bagian dari Lembaga pembiayaan non Bank yang melakukan usaha Pembiayaan konsumen.

Syarat-syarat perjanjian angka 4 menyatakan bahwa :

Debitur wajib membayar angsuran, biaya-biaya ataupun denda yang wajib dibayar (jika ada) secara tepat waktu dan penuh sesuai dengan Perjanjian ini. Apabila pembayaran angsuran hanya sebagian, maka pembayaran dianggap belum dilakukan, sampai Debitur membayar penuh sesuai nilai angsuran yang ditetapkan dalam perjanjian ini. Apabila tanggal pembayaran jatuh pada hari libur, maka debitur wajib melakukan pembayaran angsuran pada hari kerja sebelum hari libur.

Menurut Pasal 1 Perjanjian pembiayaan bersama :

a. Besarnya angsuran perbulan:

Rp. 431.000

b.

anga waktu angsuran : 33 kali Angsuran, dimana angsuran pertama dimulai tanggal 14 desember 2011 sedangkan angsuran selanjutnya dibayar pada tanggal yang sama tanggal angsuran pertama.

Sehingga perjanjian antara PT Adira Finance, Tbk dengan Bapak Ade Firman adalah Perjanjian Pembiayaan Bersama dengan Penyerahan Hak Milik Secara Fidusia dapat dikategorikan sebagai perjanjian pembiayaan konsumen, karena pembiayaan bersama ini merupakan kegiatan pembiayaan untuk pengadaan barang berdasarkan kebutuhan konsumen dengan pembayaran secara angsuran, hal ini sesuai dengan isi dari Pasal 1 angka 7 Peraturan Presiden No 9 Tahun 2009, penyerahan suatu benda secara fidusia merupakan peyerahan hak milik atas jaminan akan tetapi objek jaminan masih dikuasai oleh konsumen, dokumen kepemilikan barang dikuasai oleh perusahaan pembiayaan konsumen (fiduciary transfer of ownership) sampai angsuran terakhir dilunasi.

Menurut Pasal Pasal 1 PMK 43 Tahun 2012 bahwa : "Perusahaan Pembiayaan yang melakukan kegiatan usaha pembiayaan konsumen dan pembiayaan konsumen berdasarkan prinsip syariah untuk kendaraan bermotor wajib menerapkan ketentuan uang muka (down payment) kepada konsumen sebagai berikut: "Bagi kendaraan bermotor roda dua atau tiga, paling rendah 20\% (dua puluh per seratus) dari harga jual kendaraan yang bersangkutan; "

Berkaitan dengan tanggung jawab terhadap objek perjanjian, maka tanggung jawab itu akan dipikul oleh pelaku usaha dalam penelitian ini yaitu oleh PT. Adira Finance, Tbk. Pelaku usaha menurut Pasal 1 ayat (3) UU No. 8 Tahun 1999 tentang Perlindungan Konsumen yaitu setiap perseorangan atau badan usaha, baik yang berbentuk badan hukum maujpun bukan badan hukum yang didirikan dan berkedudukan atau melakukan kegiatan dalam wilayah hukum negara Republik Indonesia, balk sendiri maupun bersama-sama melalui perjanjian penyelenggaraan kegiatan usaha dalam berbagai bidang ekonomi.

PT. Adira Finance, Tbk diberikan hak sebagaimana yang diatur dalam Pasal 6 UUPK. Hak Pelaku Usaha adalah:

1) Hak untuk menerima pembayaran yang sesuai dengan kesepakatan mengenai kondisi dan nilai tukar barang dan/atau jasa yang diperdagangkan;

2) Hak untuk mendapatkan perlindungan hukum dari tindakan konsumen yang tidak beriktikad tidak balk;

3) Hak untuk melakukan pembelaan diri sepatutnya di dalam penyelesaian hukum sengketa konsumen;

4) Hak untuk rehabilitasi nama balk apabila tidak terbukti secara hukum 
bahwa kerugian konsumen tidak diakibatkan oleh barang dan/atau jasa yang diperdagangkan;

5) Hak-hak yang diatur dalam ketentuan peraturan perundang-undangan lainnya.

\section{Kewajiban PT. Adira Finance Tbk}

Pelaku usaha PT. Adira Finance, Tbk dibebankan pula kewajiban-kewajiban sebagai-mana diatur dalam Pasal 7 UUPK, yakni:

1. Beriktikad baik dalam melakukan kegiatan usahanya;

2. Memberikan informasi yang benar, jelas, dan jujur mengenai kondisi dan jaminan barang dan/atau atau jasa serta memberi penjelasan penggunaan, perbaikan, dan pemeliharaan;

3. Memperlakukan atau melayani konsumen secara benar dan jujur serta tidak diskriminatif;

4. Menjamin mutu barang dan/atau jasa yang diproduksi dan/atau diperdagangkan berdasarkan ketentuan standar mutu barang dan/atau jasa yang berlaku;

5. Memberi kesempatan kepada konsumen untuk menguji, dan/atau mencoba barang dan/atau jasa tertentu serta memberi jaminan dan/atau garansi atas barang yang dibuat dan/ atau diperdagangkan;

6. Memberi kompensasi, ganti rugi dan/ atau penggantian atas kerugian akibat penggunaan, pemakaian dan pemanfaatan barang dan/atau jasa yang diperdagangkan;

7. Memberi kompensasi, ganti rugi dan/ atau penggantian apabila barang dan/atau jasa yang diterima atau dimanfaatkan tidak sesuai dengan perjanjian.

Tanggung jawaban PT. Adira Finance terhadap Objek Perjanjian, yaitu kewajiban terhadap segala sesuatunya, fungsi menerima pembebanan sebagai akibat sikap tidak sendiri atau pihak lain.

Bicara mengenai kedudukan konsumen dalam hubungan hukum dengan pelaku usaha, yaitu: Teori Let The Buyer Beware (Caveat Emptor), teori ini berpendapat bahwa pelaku usaha dan konsumen adalah dua pihak yang sangat seimbang, sehingga tidak perlu ada proteksi apapun bagi konsumen.

Apabila berpegang pada teori ini, tentunya masing-masing pihak (konsumen dan pelaku usaha) mempunyai kedudukan yang sama dalam dunia usaha. Hal ini jelas dapat diterima karena masing-masing pihak, balk pelaku usaha dan konsumen, saling berketergantungan satu sama lainnya. Pelaku usaha tidak akan mungkin dapat tumbuh dan berkembang tanpa dukungan dari konsumen, dan sebaliknya konsumen pun tidak akan dapat memenuhi kebutuhannya jika tidak ada pelaku usaha.

Namun kondisi ini (dikaitkan dengan teori Let the Buyer Beware) dalam perkembangan prakteknya ternyata tidak berjalan sebagaimana mestinya. Sering kali dapat dijumpai dalam prakteknya justru pihak konsumen lah yang menjadi pihak yang lemah. Hal ini jelas terlihat dimana konsumen sering kali tidak mendapatkan akses informasi yang cukup akan barang dan/atau jasa yang tersedia di masyarakat. Memang tidak dapat dipungkiri bahwa di satu sisi adanya keterbatasan pengetahuan dari konsumen, mengingat tidak konsumen mempunyai pengetahuan, dan kedudukan yang sosial ekonomi yang sama. Namun di sisi lain justru kondisi konsumen tersebut dimanfaatkan oleh pelaku usaha untuk menarik keuntungan dengan tidak keterbukaan pelaku usaha terhadap produk yang ditawarkannya. Akhirnya konsumenlah yang didikte oleh pelaku usaha. Jika konsumen mengalami atau menderita kerugian, pelaku usaha dapat dengan ringan berdalih, semuanya itu karena kelalaian konsumen itu sendiri. 
Pada akhirnya dalam perkembangannya teori let the buyer beware ini ditentang oleh pendukung gerakan perlindungan konsumen.

Dalam perjanjian antara PT. Adira Finance, Tbk dengan konsumen terdapat klausul yang memiliki potensi merugikan konsumen yaitu berkaitan dengan objek perjanjian berdasarkan.

\section{a. Angka 13 syarat perjanjian}

Seluruh kewajiban Debitur kepada Kreditur, dapat ditagih seketika dan sekaligus tanpa pemberitahuan secara tertulis terlebih dahulu kepada debitur atau tanpa somasi lagi, sehingga suatu peringatan dengan surat juru sita atau surat lainnya tidak diperlukan lagi. Apabila terjadi salah satu keadaan;

1) Debitur lalai membayar angsuran secara penuh pada tanggal yang telah ditetapkan, atau debitur dan/atau Penjamin lalai tidak memenuhi syarat-syarat dalam perjanjian ini atau perjanjian/pernyataan lain yang berhubungan dan merupakan satu kesatuan dengan perjanjian ini dan/atau perjanjian lainnya yang terpisah dai perjanjian ini;

2) Jaminan dipindahtangankan atau dijaminkan kepada pihak ketiga tanpa ijin tertulis sebelumnya dari kreditur, atau disita oleh instansi yang berwenang, atau hilang, rusak, atau musnah karena sebab apapun juga.

Dalam Klausula ini tidak ada tolerasi dari phak PT. Adira Finance, Tbk terhadap objek yang diperjanjikan hilang, rusak atau musnah tetap pihak debitur harus membayar kewajibannya.

\section{b. Kemudian berdasarkan angka 14 syarat perjanjian}

Untuk menjamin pembayaran seluruh kewajiban Debitur kepada Kreditur berdasarkan Perjanjian ini, Debitur dan/atau Penjamin dengan ini menyerahkan kepa- da Kreditur hak miliknya secara fiducia atas jaminan dengan syarat-syarat dan ketentuan-ketentuan sebagai berikut:

Huruf e "Selama jangka waktu Perjanjian ini, segala beban pajak dan lainnya yang sekarang dan di kemudian hari akan dikenakan atas jaminan (bila ada) akan menjadi beban Debitur dan/atau Penjamin. Selama jangka waktu Perjanjian, Jaminan akan diasuransikan oleh Kreditur. Segala kerusakan dan kehilangan atau resiko lain pada jaminan, Debitur dan/atau Penjamin harus segera melaporkannya kepada kreditur dalam waktu 24 jam setelah kejadian tersebut berlangsung. Pelanggaran terhadap ketentuan ini tidak dapat dijadikan alasan untuk tidak melaksanakan atau menunda kewajiban pembayaran angsuran Debitur kepada Kreditur.

Jaminan atau objek perjanjian selama perjanjian akan diasuransikan, maka dari klausula ini dapat dilihat bahwa PT. Adira Finance, Tbk melepaskan segala tanggung jawabnya kepada pihak ketiga yaitu pihak asuransi dalam perjanjian ini yaitu Asuransi Autocilin. Segala kerusakan dan kehilangan atau resiko lain pada jaminan, Debitur dan/atau Penjamin harus segera melaporkannya kepada kreditur dalam waktu 24 jam setelah kejadian tersebut berlangsung. Kerusakan yang bagaimana yang dapat di claim oleh asuransi ini tidak jelas dalam perjanjian disebutkan, dalam perjanjian asuransinya disebutkan hanya TLO (Total Loss Only) hanya kehilangan saja yang akan mendapat penggantian dari asuransi, sedangkan kerusakan tidak mendapat penggantian.

"Pelaku Usaha bertanggung jawab memberikan ganti rugi atas kerusakan, pencemaran, dan/atau kerugian konsumen akibat mengkonsumsi barang dan/atau jasa yang dihasilkan atau diperdagangkan".

Berdasarkan uraian yang telah Dianalisis, maka dapat disimpulkan bahwa tanggung jawab PT. Adira Finance, Tbk 
selaku perusahaan pembiayaan dalam isi perjanjian dapat mengindarkan diri dari tanggung jawab seperti yang tertuang dalam angka 14 huruf e yaitu "Selama jangka waktu Perjanjian ini, segala beban pajak dan lainnya yang sekarang dan di kemudian hari akan dikenakan atas jaminan (bila ada) akan menjadi beban Debitur dan/atau Penjamin. Selama jangka waktu Perjanjian, Jaminan akan diasuransikan oleh Kreditur. Segala kerusakan dan kehilangan atau resiko lain pada jaminan, Debitur dan/atau Penjamin harus segera melaporkannya kepada kreditur dalam waktu 24 jam setelah kejadian tersebut berlangsung. Pelanggaran terhadap ketentuan ini tidak dapat dijadikan alasan untuk tidak melaksanakan atau menunda kewajiban pembayaran angsuran Debitur kepada Kreditur" sehingga jika terjadi masalah dikemudian hari pihak Pelaku Usaha dapat menghindarkan diri dari tang ung jawabnya.

Perlindungan hukum terhadap konsumen dalam Perjanjian Pembiayaan Bersama antara konsumen dengan PT Adira Finance, Tbk. Sejak zaman Hindia Belanda Peraturan perlindungan terhadap konsumen telah ada dalam bentuk Ordonansi, selain itu dalam Burgerlijk Wetboek atau sekarang lebih dikenal dengan nama Kitab Undang-Undang Hukum Perdata juga terdapat ketentuanketentuan yang memiliki tendensi perlindungan terhadap konsumen yaitu Pasal-Pasal dalam Buku Ill, bab V bagian $\mathrm{H}$ yang dimulai dari Pasal 1365 .

Peraturan Perlindungan Konsumen yang dibuat dalam suatu Undang-Undang baru terealisasi tahun 1999 melalui Undang-Undang Nomor 8 Tahun 1999 tentang Perlindungan Konsumen, yang diundangkan pada tanggal 20 April tahun 1999 dalam Lembaran Negara Tahun 1999 Nomor 42, dan berlaku efektif satu tahun setelah diundangkan yaitu sejak tanggal 20 April 2000.

Undang-undang ini diharapkan dapat mendidik masyarakat untuk lebih menyadari hak-hak dan kewajiban-kewajiban yang dimiliki pelaku usaha. Sehingga konsumen mempunyai kesadaran, pengetahuan, kepedulian, kemampuhan, dan kemandirian konsumen untuk melindungi dirinya, serta menumbuhkan sikap pelaku uasaha yang bertanggungjawab.

Dilihat dari cakupan materinya, yang mempersoalkan masalah standar kontrak dan tanggung jawab produk, maka hukum perlindungan konsumen masuk kedalam kelompok hukum privat karena kedua masalah tersebut mempersoalkan hak-hak privat (hak keperdataan) dari konsumen yang timbuk sehubungan dengan memperoleh dan memakai produk.

Akan tetapi, dilihat dari konteks hidup bernegara yang berwawasan pembangunan yang menuju kesejahteraan bersama (welfae state) maka norma-norma hukum politikpun ikut dipertahankan sebab sebagaimanapun seorang konsumen yang juga adalah warganegara, merupakan sumber daya pembangunan yang perlu dijaga kualitas hidupnya sehingga mampu melanjutkan kesinambungan pembangunan suatu negara. Oleh karena itu, hukum perlindungan konsumen juga termasuk dalam hukum publik.

Kalau melihat pada penegakan hukumnya bahwa hak-hak konsumen dapat ditegakkan secara perdata, yaitu melalui peradilan perdata (perkara Perdata) dan jugs pidana yaitu memakai KUH Perdatadan HIR/ RBg serta KUH Pidana dengan KHUAP. Artinya, seorang konsumen yang dirugikan haknya dapat mengajukan gugatan ke Pengadilan dan sebaliknya dalam hal tertentu seorang produsen yang menimbulkan kerugian kepada konsumen dapat dituntut pertanggungjawabannya secara pidana karena di dalamnya terkait norma-norma hukum pidana.

Pada umumnya para pelaku usaha berlindung dibalik Standard Contract atau 
Perjanjian Baku yang telah ditandatangani oleh keduabelah pihak (antara pelaku usaha dan konsumen), Konsumen atau masyarakat adakalanya tidak mengetahui dengan jelas yang menjadi hak-hak dan kewajibankewajiban dari atau terhadap pelaku usaha.

Pengertian perlindungan konsumen yang terdapat dalam Pasal 1 angka 1 Undang-Undang Nomor 8 Tahun 1999 tentang Perlindungan Konsumen /UUPK yaitu:

"Perlindungan konsumen adalah segala upaya yang menjamin adanya kepastian hukum untuk memberi perlindungan kepada konsumen".

Adapun tujuan penyelenggaraan, pengembangan dan pengaturan perlindungan konsumen yang direncanakan adalah untuk meningkatkan martabat dan kesadaran konsumen, dan secara tidak langsung mendorong pelaku usaha dalam penyelenggarakan kegiatan usahanya dengan penuh rasa tanggung jawab.

Nasution berpendapat bahwa hukum perlindungan konsumen adalah bagian dari hukum konsumen yang memuat asas-asas atau kaidah-kaidah yang bersifat mengatur dan mengandung sifat yang melindungi kepentingan konsumen, sedangkan hukum konsumen adalah hukum yang mengatur hubungan dan masalah antara berbagai pihak satu sama lain berkaitan dengan barang atau jasa.

Pengaturan perlindungan konsumen dilakukan dengan :

1. Menciptakan sistem perlindungan konsumen yang mengandung akses dan informasi, serta menjamin kepastian hukum;

2. Melindungi kepentingan konsumen pada khususnya dan kepentingan seluruh pelaku usaha pada umumnya;

3. Meningkatkan kualitas barang dan pelayanan jasa

4. Memberikan perlindungan kepada konsumen dari praktik usaha yang menipu dan menyesatkan;

5. Memadukan penyelenggaraan, pengembangan dan pengaturan perlindungan konsumen dengan bidang-bidang perlindungan pada bidang-bidang lainnya.

Asas Manfaat ini mengamanatkan bahwa segala upaya dalam penyelenggaraan perlindungan konsumen harus memberikan manfaat sebesar-besarnya untuk kepentingan konsumen dan pelaku usaha secara bersamaan.

Asas ini menghendaki bahwa pengaturan dan penegakan hukum perlindungan konsumen tidak dimaksudkan untuk menempatkan salah satu pihak di atas pihak lain atau sebaliknya, tetapi untuk memberikan perlindungan kepada masing-masing pihak yaitu kepada produsen dan konsumen apa yang menjadi haknya dan berada pada posisi sejajar.

Asas Keadilan agar partisipasi seluruh masyarakat dapat diwujudkan secara maksimal dan dapat memberikan kesempatan kepada konsumen dan pelaku usaha untuk menempatkan haknya dan melaksanakan kewajibannya secara adil.

\section{Kewajiban konsumen}

Selain memperoleh hak tersebut, konsumen juga mempunyai kewajiban. Ketentuan kewajiban konsumen dapat kita lihat dalam Pasal 5 UUPK, yaitu

1. Membaca atau mengikuti petunjuk informasi dan prosedur pemakaian atau pemanfaatan barang dan/atau jasa, demi keamanan dan keselamatan;

2. Beriktikad baik dalam melakukan transaksi pembelian barang dan/ atau jasa;

3. Membayar sesuai dengan nilai tukar yang disepakati;

4. Mengikuti upaya penyelesaian hukum sengketa perlindungan konsu- 
men secara patut.

Dalam Perjanjian antara PT. Adira Finance, Tbk dengan konsumen terdapat pula hak dan kewajiban konsumen yaitu :

Hak Konsumen

1. Konsumen berhak atas pencairan fasilitas pembiayaan bersama dilakukan oleh Pelaku Usaha setelah Konsumen memenuhi seluruh kewajiban yang ditentukan oleh Pelaku Usaha (syarat perjanjian angka 1)

2. Konsumen berhak untuk melakukan pembayaran dipercepat baik sebagian atau seluruhnya (syarat perjanjian angka 7)

3. Konsumen berhak atas Jaminan tetap dalam penguasaan oleh Konsumen tidak lagi sebagai pemilik melainkan sebagai peminjam atau pemakai jaminan (syarat perjanjian angka 14 huruf a)

4. Untuk setiap hari keterlambatan pembayaran yang wajib dibayar berdasarkan perjanjian ini, maka Debitur dikenakan denda atas jumlah yang tertunggak sebesar 0,5 $\%$ per hari keterlambatan untuk Fasilitas Pembiayaan Bersama kendaraan roda dua dan 0,2 \% per hari keterlambatan unuk Fasiltas Pembiayaan Bersama kendaraan roda empat. Denda harus dibayar secara seketika dan sekaligus tanpa diperlukan teguran untuk itu pada saat ditagih.

5. Jaminan, yaitu terdiri atas jaminan utama, jaminan pokok, dan jaminan tambahan, jaminan utama berupa kepercayaan terhadap konsumen (debitur) bahwa konsumen dapat dipercaya untuk membayar angsurannya oleh perusahaan pembiayaan konsumen dimana semua dokumen kepemilikan barang dikuasai oleh perusahaan pembiayaan konsumen (fiduciary transfer of ownership) sampai angsuran terakhir dilunasi. Adapun jaminan tambahan berupa pengakuan utang (promissory notes) dari konsumen.

Jaminan Untuk Menjamin Pembayaran Kembali seluruh kewajiban konsumen kepada Pelaku Usaha berikut bunga, denda, provisi serta biaya-biaya lain yang mungkin timbul berdasarkan Perjanjian. Konsumen dan atau pelaku usaha menjaminkan barang jaminan berupa kendaraan bermotor dengan merek Yamaha Mio CW dan Nomor mesin 2SD3435531, Nilai Jaminan Rp. 12.550.000,00, Nilai Penjaminan (Nilai AR) : Rp. 16.804.757,00. Perlindungan terhadap konsumen tidak terlepas perjanjian baku atau perjanjian standard yang dibuat Pelaku usaha yaitu PT. Adira Finance, Tbk:

Perjanjian Baku adalah kontrak berbentuk tertulis yang telah digandakan berupa formulir-formulir, yang isinya telah distandarisasi atau dibakukan terlebih dahulu secara sepihak oleh pihak yang menawarkan (pelaku usaha) serta ditawarkan secara massal, tanpa mempertimbangkan perbedaan kondisi yang dimiliki konsumen.

Yang dimaksud dengan Klausula baku menurut Pasal 1 angka 10 Undang-Undang Perlindungan Konsumen Nomor 8 Tahun 1999 adalah: "Klausula baku adalah setiap aturan atau ketentuan dan syarat-syarat yang telah dipersiapkan dan ditetapkan terlebih dahulu secara sepihak oleh pelaku usaha yang dituangkan dalam suatu dokumen dan atau/atau perjanjian yang mengikat dan wajib dipenuhi oleh konsumen."

Sutan Remi Sjandeni mengartikan perjanjian standar sebagai perjanjian yang hampir seluruh klausul-klausulnya dibakukan oleh pemakainya dan pihak yang lain pada dasarnya tidak mempunyai peluang untuk merundingkan atau meminta perubahan. 
Dalam perjanjian baku terdapat klausul baku yang merupakan pernyataan yang ditetapkan secara sepihak oleh salah satu pihak, lazimnya adalah pelaku usaha.

Perjanjian Baku adalah kontrak berbentuk tertulis yang telah digandakan berupa formulir-formulir, yang isinya telah distandarisasi atau dibakukan terlebih dahulu secara sepihak oleh pihak yang menawarkan (pelaku usaha) serta ditawarkan secara massal, tanpa mempertimbangkan perbedaan kondisi yang dimiliki konsumen.

Dalam ketentuan Pasal 18 ayat (1) UUPK dikatakan bahwa para pelaku usaha dalam menawarkan barang dan atau jasa yang ditujukan untuk diperdagangkan dilarang mencantumkan klausula baku pada setiap dokumen dan/atau perjanjian dimana klusula baku tersebut akan mengakibatkan:

1. Pengalihan tanggung jawab pelaku usaha

2. Menyatakan bahwa pelaku usaha berhak menolak penyerahan kembali barang yang dibeli konsumen

3. Menyatakan bahwa pelaku usaha berhak menolak peyerahan kembali uang yang dibayarkan atas barang dan atau jasa yang dibeli oleh konsumen

4. Menyatakan pemberian kuasa dari konsumen kepada pelaku usaha, baik secara langsung maupun tidak Iangsung untuk melakukan segala tindakan sepuhak yang berkaitan dengan barang yang dibeli oleh konsumen secara angsuran

5. Mengatur perihal pernbuktian atas hilangnya kegunaan barang atau pemanfaatan jasa yang dibeli oleh konsumen

6. Memberi hak kepada pelaku usaha untuk mengurangi manfaat jasa atau mengurangi harta kekayaan konsumen yang menjadi objek jual beli jasa
7. Menyatakan tunduknya konsumen kepada peraturan yang berupa aturan baru, tambahan, lanjutan, dan/atau perubahan lanjutan yang dibuat sepihak oleh pelaku usaha dalam masa konsumen memanfaatkan jasa yang dibelinya

8. Menyatakan bahwa konsumen memberi kuasa kepada pelaku usaha untuk pembebanan hak tanggungan, hak gadai, atau hak jaminan terhadap barang yang dibeli oleh konsumen secara angsuran.

Dalam perjanjian baku terdapat klausul baku yang merupakan pernyataan yang ditetapkan secara sepihak oleh salah satu pihak, lazimnya adalah pelaku usaha, sehingga konsumen hanya mempunyai pilihan menyetujui atau menolaknya. Penetapan secara sepihak ini biasanya menimbulkan masalah karena bersifat berat sebelah. Di antara klausul baku yang dinilai memberatkan dalam suatu perjanjian baku adalah klausula eksonerasi.

Klausula eksonerasi atau klausula eksemsi adalah yang berisi pembatasan pertanggungjawaban dari kreditur. Klausula ini bertujuan untuk membebaskan atau membatasi tanggung jawab salah satu pihak terhadap gugatan pihak lainnya dalam hal yang bersangkutan tidak atau tidak dengan semestinya melaksanakan kewajibannya yang ditentukan dalam perjanjian tersebut.

Klausula eksonerasi yang muncul dalam perjanjian pembiayaan misalnya klausula yang menyatakan bahwa perusahaan tidak bertanggung jawab atas segala kerusakan dan kehilangan. Klausula tersebut membatasi tanggung jawab pelaku usaha/kreditur untuk membayar ganti rugi kepada konsumen/debitur. 


\section{PENUTUP}

\section{Kesimpulan}

Berdasarkan isi perjanjian Pembiayaan Bersama yang telah dilakukan antara PT. Adira Finance, Tbk dengan Konsumen, maka PT. Adira Finance, Tbk sebagai pelaku usaha dapat menghindarkan diri untuk tidak bertanggung jawab atas objek perjanjian, sebagaimana tertuang dalam syarat perjanjian angka 14 huruf (e) "Huruf e "Selama jangka waktu Perjanjian, Jaminan akan diasuransikan oleh Kreditur. Segala kerusakan dan kehilangan atau resiko lain pada jaminan, Debitur dan/atau Penjamin harus segera melaporkannya kepada kreditur dalam waktu 24 jam setelah kejadian tersebut berlangsung. Pelanggaran terhadap ketentuan ini tidak dapat dijadikan alasan untuk tidak melaksanakan atau menunda kewajiban pembayaran angsuran Debitur kepada Kreditur.

Dalam isi Perjanjian Bersama yang dilakukan secara sepihak oleh PT. Adira Finance, Tbk selaku pelaku usaha, sebagai suatu perjanjian baku, tidak terdapat perlindungan hukum bagi konsumen, dalam arti bahwa isi perjanjian tersebut menempatkan konsumen selalu dipihak yang Iemah, hal ini dapat dilihat dalam syarat perjanjian angka 14 yang isinya bertentangan dengan Pasal 19 UUPK:

"Untuk menjamin pembayaran seluruh kewajiban Debitur kepada Kreditur berdasarkan Perjanjian ini, Debitur dan/atau Penjamin dengan ini menyerahkan kepada Kreditur hak miliknya secara fiducia atas jaminan dengan syarat-syarat dan ketentuan-ketentuan sebagai berikut: Huruf d "Kreditur atau wakilnya berhak untuk setiap waktu, atas beban/biaya Debitur dan/atau penjamin untuk : i) memasuki tempat dimmana jaminan tersebut berada; ii) memeriksa keadaan jaminan; iii) melakukan dan menyuruh
Debitur dan/atau Penjamin melakukan sesuai butir c diatas jika Debitur lalai dan; iv) menempatkan/membuat tanda pada jaminan yang menunjukan hak dan kepentingan Kreditur.

Huruf e "Selama jangka waktu Perjanjian ini, segala beban pajak dan lainnya yang sekarang dan di kemudian hari akan dikenakan atas jaminan (bila ada) akan menjadi beban Debitur dan/atau Penjamin. Selama jangka waktu Perjanjian, Jaminan akan diasuransikan oleh Kreditur. Segala kerusakan dan kehilangan atau resiko lain pada jaminan, Debitur dan/atau Penjamin harus segera melaporkannya kepada kreditur dalam waktu 24 jam setelah kejadian tersebut berlangsung. Pelanggaran terhadap ketentuan ini tidak dapat dijadikan alasan untuk tidak melaksanakan atau menunda kewajiban pembayaran angsuran Debitur kepada Kreditur.

Huruf f "Apabila Debitur tidak melunasi seluruh atau sebagian kewajibannya kepada Kreditur, maka Kreditur berhak dan dengan ini diberi kuasa dengan hak substitusi oleh Debitur dan/atau Penjamin untuk ; i) mengambil di manapun dan di tempat siapapun jaminan itu berada; ii) menjual dimuka umum atau secara dibawah tangan atau dengan perantara pihak lain dimana Jaminan dengan harga pasar yang layak dan dengan syarat-syarat dan ketentuan yang dianggap baik oleh kreditur.

Setelah Jaminan ditarik atau diambil alih oleh Kreditur ("BJDA'), Kreditur berhak; i) melaksanakan penjualan atas BJDA; ii)menghadap kepada siapapun dan dimanapun, memberikan dan meminta keterangan, membuat/menyuruh membuat akta/perjanjian menandatangani tanda penerimaannya, menyerahkan Jaminan kepada yang berhak menerimanya dan iii) melakukan tindakan tanpa ada yang dikecualikan guns tercapainya penjualan BJDA tersebut.

Uang hasil penjualan BJDA, akan 
diperuntukan untuk ; i) ongkos dan pajak yang timbul sehubungan dengan penjualan BJDA; ii) pokok pinjaman; iii) kewajiban lainnya termasuk bungs dan Benda (jika ada). Apabila masih terdapat sisa uang, Kreditur akan menyerahkan sisa tersebut kepada Debitur dan/atau Penjamin, sebaliknya apabila uang hasil penjualan itu tidak cukup untuk melunasi seluruh kewajiban Debitur kepada Kreditur, maka debitur tetap berkewajiban membayar sisa kewajiban yang masih terhutang tersebut kepada Kreditur selambat-Iambatnya dalam waktu satuminggu setelah pemberitahuan Kreditur kepada Debitur.

Pasal 19 UUPK mengemukakan bahwa: "Pelaku usaha dalam menawarkan barang dan/atau jasa yang ditujukan untuk diperdagangkan dilarang membuat atau mencantumkan klausula baku pada setiap dokumen dan/atau perjanjian apabila:

a. Menyatakan pengalihan tanggung jawab pelaku usaha;

b. Menyatakan bahwa pelaku usaha berhak menolak penyerahan kembali barang yang dibeli konsumen

c. Menyatakan bahwa pelaku usaha berhak menolak penyerahan kembali uang yang dibayarkan atas barang dan/atau jasa yang dibeli oleh konsumen;

d. Menyatakan pemberian kuasa dari konsumen kepada pelaku usaha baik secara langsung maupun tidak langsung untuk melakukan segala tindakan sepihak yang berkaitan dengan barang yang dibeli oleh konsumen secara angsuran;

e. Mengatur perihal pembuktian atas hilangnya kegunaan barang atau pemanfaatan jasa yang dibeli oleh konsumen;

f. Memberi hak kepada pelaku usaha untuk mengurangi manfaat jasa atau mengurangi harta kekayaan konsu men yang menjadi objek jual bell jasa; g. Menyatakan tunduknya konsumen kepada peraturanyan berupa aturan baru, tambahan, lanjutan dan/atau pengubahan lanjutan yang dibuat sepihak oleh pelaku usaha dalam masa konsumen memanfaatkan jasa yang dibelinya;

h. Menyatakan bahwa konsumen memberi kuasa kepada pelaku usaha untuk pembebanan hak tanggungan, hak gadai, atau hak jaminan terhadap barang yang dibeli oleh konsumen secara angsuran."

\section{Saran}

PT. Adira Finance, Tbk untuk objek perjanjian selama rentan waktu perjanjian diasuransikan penulis sarankan tidak hanya kehilangan saja yang diganti oleh pihak asuransi akan tetapi lebih untuk menjamin kepuasan konsumen, termasuk kerusakan kecil sampai kerusakan berat ditanggung oleh pihak asuransi.

PT. Adira Finance, Tbk seharusnya mendaftarkan fidusia berdasarkan ketentuan PMK Nomor 130 Tahun 2012 dan adanya penambahan klausula jangka waktu atau berapa kali angsuran jika jaminan akan disita oleh pihak PT. Adira Finance, Tbk.

PT. Adira Finance, Tbk, seharusnya sebelum melaksanakan isi perjanjian, menambahkan klausula yang melindungi konsumen, Pemerintah melakukan pengawasan terhadap Perusahaan Pembiayaan yang dengan melihat isi perjanjian yang berhubungan dengan klausula eksonerasi.

\section{DAFTAR PUSTAKA}

Abdul Kadir Muhammad, Hukum Perjanjian, Bandung: Alumni, 1982

Abdul Halim Barkatulah, Hukum Perlindungan Konsumen (Kajian Teoretis 
dan Perkembangan Pemikiran, Bandung, Nusa Media, 2008

Az. Nasution, Hukum Perlindungan Konsumen Suatu Pengantar, Jakarta: Diadit Media, 2001

Bambang Waluyo, Penelitian Hukum Dalam Praktek, Sinar Grafika, Jakarta, 1991

Celina Tri Siwi Kristiyanti, Hukum Perlindungan Konsumen, Jakarta: Sinar Grafika, 2009

Geoff Monahan and David Barker, Essential Contract Law (Second Edition), Cavendish Publishing, Sydney, 2001

Gunawan Wijaya \& Ahmad Yani, Hukum Tentang Perlindungan Konsumen, Jakarta: PT. Gramedia Pustaka Utama, 2000

H. Hari Saherodji, Pokok-Pokok Hukum Perdata, Jakarta: Aksara Baru, 1980

Happy Susanto, Hak-Hak Konsumen Jika Dirugikan, Jakarta: Visimedia, 2008

Heru P. Sanusi, dkk, Hukum Dagang, Jakarta: Fakultas Hukum Universitas Trisakti, 2009

Janus sidabalok, Hukum Perlindungan Konsumen di Indonesia, Bandung, PT Citra Aditya Bakti, 2014

Lukman Santoso, Hukum Perjanjian Kontrak Yogyakarta: Cakrawala, 2012

M. Yahhya Harahap, Segi-Segi Hukum Perjanjian, Bandung: Alumni,1986.

Mariam Darus Badrulzaman, Aneka Hukum Bisnis, Bandung: Alumni,
1994

Mariam Darus Badrulzaman, Perjanjian Kredit Bank, Bandung: PT Citra Aditya, 1991

Munir Fuady, Hukum Tentang Pembiayaan Dalam Teori Dan Praktek, Bandung: PT. Citra Aditya bakti, 1995

Pedoman Penulisan Skripsi Fakultas Hukum Universita Trisakti, Jakarta: Universitas Trisakti, 2011

RM. Sudikno Mertokusumo, Mengenal Hukum (Suatu Pengantar), Yogyakarta: Liberty, 1988

Satrio, J., Hukum Perikatan, Perikatan Yang Lahir Dari Perjanjian, Buku I, Setiawan, R., Pokok-Pokok Hukum Perikatan, Bandung: Binacipta, 1994

Shidarta, Hukum Perlindungan Konsumen Indonesia Edisi Revisi 2006, Jakarta: Gramedia Widiasarana Indonesia, 2006

Soerjono Soekanto, Pengantar Penelitian Hukum, (Jakarta: Universitas Indonesia, 2006), Soerjono Soekanto, Pengantar Penelitian llmu Hukum, (Jakarta: Universitas Indonesia Press, 1986)

Sri Gambir Melati Hatta, Bell Sewa Sebagai Perjanjian Tak Bemama: Pandangan Masyarakat Dan Sikap Mahkamah Agung, Bandung: Alumni, 1999

Subekti, Hukum Perjanjian, Jakarta: PT. Intermasa, 1985. Subekti, R, Aneka Perjanjian, Alumni, Bandung 1994.

Subekti,R, Aspek-Aspek Hukum Perikatan Nasional, Alumni, Bandung, 1992 
Sudaryatmo, Masalah Perlindungan Konsumen di Indonesia, Citra Adiya Bakti, Bandung, 1996

Sudikno Metokusumo, Mengenal Hukum (Suatu Pengantar), Yogyakarta: Liberty, 1985

Sutan Remy Sjandeini, Kebebasan Berkontrak dan Perlindungan Yang Seimbang Bagi Para Pihak Dalam Perjanjian Kredit Bank di Indonesia, Jakarta, Institut Bankir Indonesia, 1993

T.M. Scanlon, "Promises and Contracts", dalam Peter Benson (ed), The Theory of Contract Law, Cambridge University Press, New York 2001

Tim Prima Pena, Kamus Besar Bahasa Indonesia, Gitamedia Press

Yusuf Shofie, Perlindungan Konsumen dan Instrumen Hukumnya, Citra aditya Bakti, Bandung, 2000

\section{PERATURAN PERUNDANG-UNDANGAN}

KUH Perdata;

Undang-Undang Perlindungan Konsumen No 8 Tahun 1999;

Peraturan Presiden Nomor 9 Tahun 2009 Tentang Lembaga Pembiayaan;

Peraturan Menteri Keuangan No130 Tahun 2012 tentang Pendaftaran Jaminan Fidusia Bagi Perusahaan Pembiayaan yang Melakukan Pembiayaan Konsumen Untuk Kendaraan bermotor;
Peraturan Menteri keuangan No 43 Tahun 2012 Tentang Uang Muka Pembiayaan Konsumen Untuk Kendaraan Bermotor pada Perusahaan Pembiayaan;

Peraturan Menteri Keuangan No 84 Tahun 2006 Tentang Perusahaan Pembiayaan;

\section{ON-LINE DARE INTERNET}

http://vvww.adira.co.id/pages/about/l/D eskripsi-Adira-Finance.

http://www.adira.co.id/pages/about/2/V isi-dan-Misi.

http://www.adira.co.id/pages/about/4/S trategi-Perusahaan 